\title{
Extreme pressure forecasting methodology for the hydraulic jump downstream of a low head spillway
}

\author{
Método de previsão de pressões extremas para o ressalto hidráulico a jusante de um \\ vertedouro de baixa queda
}

\author{
Roberta Ferrão Hampe $^{1}$ (D), Renato Steinke Júnior ${ }^{1}$ (D), Maurício Dai Prá ${ }^{1}$ (D), Marcelo Giulian Marques ${ }^{1}$ (D) \& \\ Eder Daniel Teixeira ${ }^{1}$ \\ ${ }^{1}$ Universidade Federal do Rio Grande do Sul, Porto Alegre, RS, Brasil \\ E-mails: roberta_hampe@hotmail.com (RFH), renato.steinkejunior@gmail.com (RSJ),mauricio.daipra@ufrgs.br (MDP), \\ mmarques@iph.ufrgs.br(MGM), eder.teixeira@ufrgs.br (EDT)
}

Received: May 13, 2019 - Revised: July 23, 2019 - Accepted: September 03, 2019

\begin{abstract}
Extreme pressures in the hydraulic jump are associated with risk of damage to the flow discharge system of dams by a series of mechanisms. Therefore, understanding and predicting these efforts are crucial for the safe and economical design of discharge systems. Thus, this paper aims to validate an existing pressure forecasting methodology for estimating the extreme pressure in the hydraulic jump with low Froude number (below 4.5). Results have shown that the method may be used for this situation on a preliminary basis. Further studies are recommended to refine the technique and to achieve results that are more precise.
\end{abstract}

Keywords: Stilling basin; Hydraulic jump; Chute spillway; Low Froude number; Extreme pressures.

\section{RESUMO}

Pressões extremas no ressalto hidráulico são associadas a riscos de danos no sistema extravasor de barragens por uma série de mecanismos. Assim sendo, o entendimento e a previsão destes esforços são cruciais para o dimensionamento seguro e econômico de sistemas extravasores. Este trabalho visa validar um método existente de previsão de pressões para a estimativa de pressões extremas em ressaltos hidráulicos com baixo número de Froude (abaixo de 4,5). Os resultados indicam que o método pode ser empregado para esta situação de forma preliminar. Recomenda-se que outros estudos sejam feitos para refinar a técnica e para que resultados mais precisos sejam obtidos.

Palavras-chave: Bacias de dissipação; Ressalto hidráulico; Vertedouros; Baixo número de Froude; Pressões extremas. 


\section{INTRODUCTION}

Reservoirs, natural or artificial structures used for reservation of water, can contribute to supplying water for a community, irrigation of land, flow regularization, navigation, flood control, hydraulic power generation and other benefits. For many years, mankind has used hydraulic works for many different purposes. There are records of dams and channels that preceded the year 2,000 BC, built by the Sumerian people. However, the reservation of water presents certain challenges regarding especially discharging the excess flow safely, maintaining the integrity of the structures and the river. The structures that compose the Hydroelectric Power Plants (HPPs), for instance, are subject to damages and failures due to the efforts caused by the flow. In these works, damages such as pulling out of concrete slabs, material wear, structural vibrations, geological and structural failures, abrasion, erosion and cavitation are verified (Lopardo, 2013b). Despite the advances in this field, there are still cases of damage to these structures, as occurred in 2013 at the Paradise Dam, Queensland, Australia, where the succession of floods caused significant scour of the rock body downstream the spillway (McPherson et al., 2015).

For the designing of discharge structures such as stilling basins downstream chute spillways, processes like cavitation, an erosive phenomenon regularly accompanied by noises and vibrations that occurs when the pressure reaches the vapor pressure of the liquid, may present risk and cause damage to the structure. This process is associated with the occurrence of low pressure values in the hydraulic jump. Thus, understanding pressure distribution of the hydraulic jump and being able to forecast extreme pressure is essential for the safe and economical design of stilling basins.

The most accepted and widespread classification of the hydraulic jump occurring on horizontal aprons is credited to Peterka (1974), as a function of the incident Froude number. According to the author, jumps with Froude numbers between 1.0 and 1.7 are not so expressive, presenting a slight difference in the conjugate depths and a small ruffle on the water surface. For Froude numbers between 1.7 and 2.5, the phenomenon is called a pre-jump. Small rollers are developed on the surface and the water surface is practically smooth. A rough water surface appears in the transition jump, when the incident Froude number is between 2.5 and 4.5. Large waves of irregular period that are formed in prototype can travel for miles, causing damages to earth banks and even ripraps. Jumps that occur with an incident Froude number below 4.5 are called low Froude number jumps. As the Froude number increases from 4.5 to 9.0 , the jump is well-stabilized and the energy dissipation can reach $70 \%$ of the incident energy. Jumps with Froude numbers higher than 9.0 are not desirable in prototypes, due to the high velocities and generated vortices that may cause damage to the concrete structures.

There is a great number of studies defining the external characteristics of the jump, such as the ones conducted by Rajaratnam (1967) and Elevatorski (1959). Teixeira (2003) and Trierweiler (2006) present a list of different equations derived for the determination of the sequent depth ratio. The most used, however, is the one established by Bélanger (1828), expressed as Equation 1:

$$
\frac{Y_{2}}{Y_{I}}=\frac{1}{2} \cdot\left[\sqrt{1+8 \cdot F r_{I}^{2}}-1\right]
$$

in which: $Y_{1}$ is the incident sequent depth $(\mathrm{m}) ; Y_{2}$ is the sequent depth downstream of the jump (m); $F r_{1}$ is the incident Froude number (dimensionless).
The lengths of the jump and the roller are important to know the extension of the impacts generated by the jump on the structure. The length of the jump depends largely on the definition of its end section. Elevatorski (1959) defines this section as the place where there is not much water level variance. According to Rajaratnam (1967), the jump ends at the section where the water surface becomes essentially flat and the mean water level is maximum. Drapeau et al. (1997) established Equations 2 and 3 to determine the length of the jump and roller, respectively:

$$
\begin{aligned}
& L_{j}=8.5 \cdot\left(Y_{2}-Y_{l}\right) \\
& L_{r}=6 \cdot\left(Y_{2}-Y_{l}\right)
\end{aligned}
$$

in which: $L_{J}$ is the length of the hydraulic jump (m); $L_{r}$ is the length of the roller $(\mathrm{m})$.

While experimental studies are becoming rarer, recent researches have been focusing on investigating the hydraulic jump numerically, as can be seen in Bayon et al. (2016), Jesudhas et al. (2018), Witt et al. (2018) and Valero et al. (2018). Numerical models, however, are not able to analyze and yield fluctuating nor extreme hydraulic quantities, such as velocities or pressures.

Although there is extensive literature about the macroturbulent flow and the hydraulic jump, we are still to fully understand the phenomenon regarding its internal characteristics, and new studies are still being developed. Wang \& Chanson (2015) studied the turbulent fluctuations in the hydraulic jump downstream a vertical gate and demonstrated strong interactions between the free-surface fluctuations and the jump roller turbulence. Chiew \& Emadzadeh (2017) tried to identify the differences in water profiles and pressure fluctuation between open-channel and closed-conduit hydraulic jump.

Fewer studies have been published about the forecasting of pressure distribution of the hydraulic jump, especially based on physical modelling, although they are of great importance for the design criteria of flow discharge systems.

Teixeira (2003) developed a methodology for the estimation of extreme pressures acting on stilling basins. Data from models and prototype were used in the derivation of the proposed equations, which was based on the dimensionless equations proposed by Drapeau et al. (1997). Through this method, it is possible to obtain estimates of mean and fluctuating pressure values along the hydraulic jump, as well as pressures with different probabilities of non-exceedance.

Dai Prá (2011) introduced a novel methodology for the determination of pressures occurring on the bottom of a hydraulic jump downstream of a spillway. According to the author, the pressure values must be analyzed as a summation of different hydrodynamic effects acting on the stilling basin, such as the ones caused by: the toe curve between the spillway and the horizontal apron, the supercritical flow on a horizontal surface, the macroturbulence inherent to the hydraulic jump and the degree of submergence of the phenomenon.

The mentioned publications focus on the stable hydraulic jump (with Froude number range from 4.5 to 9.0), though there is rising interest in building dams and HPPs at locations where high flowrates and low head structures allow the occurrence of low Froude number hydraulic jumps (below 4.5).

Castro-Orgaz et al. (2015b) proposed a mathematical model based on the integration of the Reynolds equations for turbulent flow aiming the appraisal of pressure distribution in the undular hydraulic jump (Froude number below 1.7). However, the results 
were not always satisfactory. Castro-Orgaz et al. (2015a) succeeded in developing an undular hydraulic jump valid for Froude numbers between 1.0 and 1.2.

Thus, this paper aims to validate the extreme pressure forecasting method provided by Teixeira (2003) on its application for low Froude number situations.

\section{MATERIALS}

For the validation of the pressure forecasting methodology proposed by Teixeira (2003) for the low Froude number application, a two-dimensional model of the discharge system of Santo Antônio HPP was built in order to collect instantaneous sample pressure data. This model was built in the Laboratório de Hidráulica Experimental e Recursos Hídricos (LAHE) of ELETROBRÁS-FURNAS (LAHE/FURNAS) in Brazil. The physical model, in the geometric scale 1:50 considering the similarity of Froude, is composed by a central channel and two lateral channels with $75 \%$ of the width of a channel, separated by two $0.10 \mathrm{~m}$ wide pillars (Figure 1). In addition, the crest of the spillway is represented with 0.19 $m$ of elevation. An overall view of the discharge system of the model is presented in Figure 2.

Water is kept at constant level in a superior tank. A cast iron hydraulic circuit leads water from this tank to the upstream part of the model. The flowrate $\mathrm{Q}$ is adjusted using electromagnetic flow meters. Above the crest of the spillway, three gates, one for each channel, allow for the adjustment of the upstream water level, as can be seen in Figure 2.

Along the dissipation basin, there are no blocks or sills, making it a Type I basin. A gate installed at the end of the channel is used to adjust the tail water of the jump and position it along the stilling basin. The incident sequent depth $\mathrm{y}_{1}$ and the upstream and tail water levels were measured using point gauges. The downstream sequent depth $\mathrm{y}_{2}$ was determined through the Bélanger equation (Equation 1).

Table 1 presents information on the test conditions. All tests were conducted with the jump starting at the beginning of the stilling basin, immediately downstream of the spillway (A-jump).

Downstream of the spillway, a $0.601 \mathrm{~m}$ long test channel was instrumented with four pressure transducers on the center line of the model, as can be seen in Figure 1. Because it is an experimental model designed for the study of the spillway of the plant, few pressure transducers were installed in the dissipation basin and these did not completely cover the extension of the hydraulic jump development. The transducers used were Sitron, model CF-12DC, with a working range from $-100 \mathrm{mbar}$ to $200 \mathrm{mbar}$. In the rectilinear section of the channel of the dissipation basin, tests were run with duration of 10 minutes, a frequency of $100 \mathrm{~Hz}$ and the Froude number varying between 1.73 and 7.56 .

Table 1. Test conditions.

\begin{tabular}{cccc}
\hline $\mathbf{Q}\left(\mathbf{m}^{3} / \mathbf{s}\right)$ & $\mathbf{F r}_{1}$ & $\mathbf{y}_{\mathbf{1}}(\mathbf{m})$ & $\mathbf{y}_{\mathbf{2}}(\mathbf{m})$ \\
\hline 0.444 & 1.73 & 0.19 & 0.38 \\
0.325 & 2.77 & 0.11 & 0.39 \\
0.276 & 3.05 & 0.09 & 0.36 \\
0.227 & 3.49 & 0.08 & 0.34 \\
0.175 & 4.26 & 0.06 & 0.31 \\
0.121 & 5.30 & 0.04 & 0.26 \\
0.069 & 7.56 & 0.02 & 0.21 \\
\hline
\end{tabular}

$\mathrm{Q}$ is flowrate; $\mathrm{Fr}_{1}$ is the incident Froude number; $\mathrm{y}_{1}$ and $\mathrm{y}_{2}$ are the sequent depths.

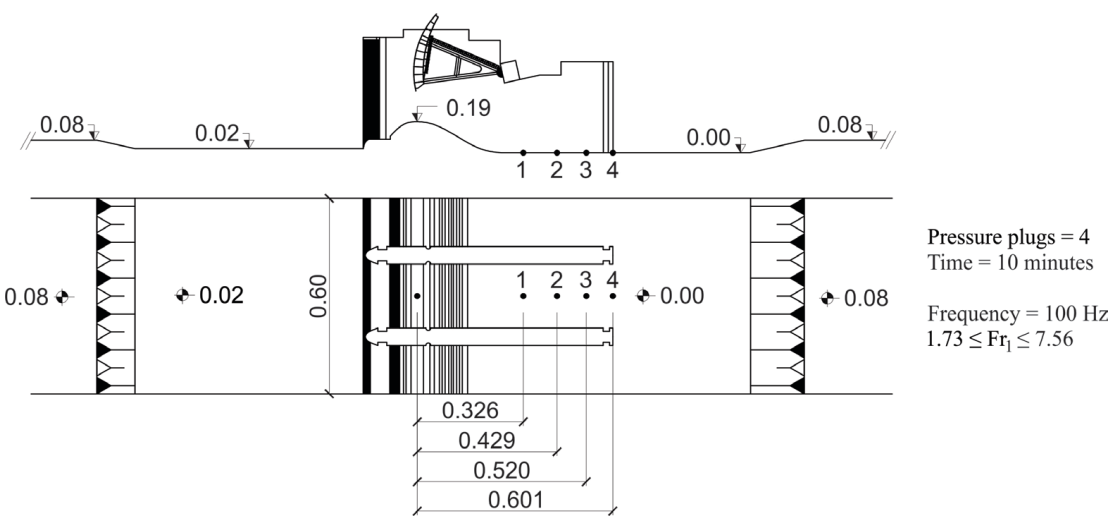

Figure 1. Santo Antônio HPP two-dimensional model (LAHE/FURNAS/Brazil) and pressure transducers locations (Souza, 2012).

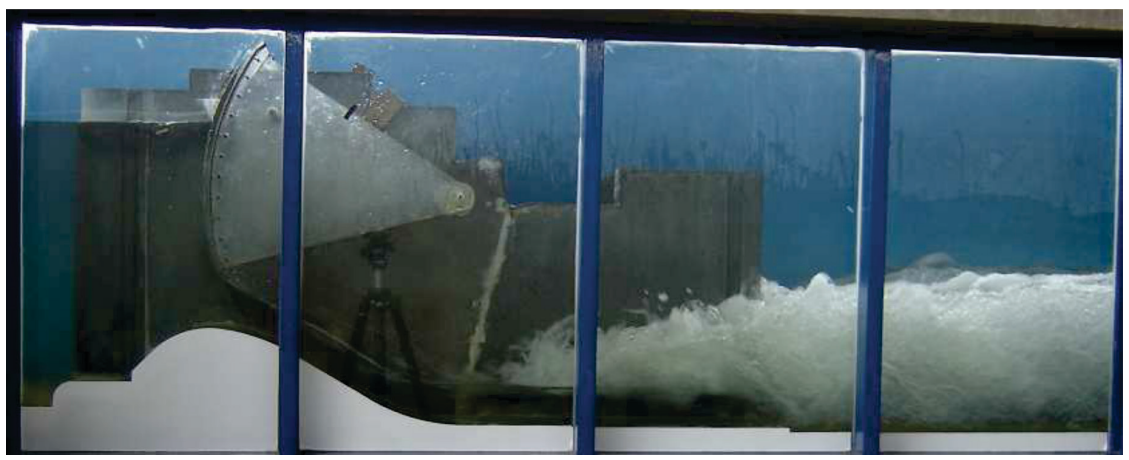

Figure 2. Hydraulic jump formed for flowrate 227 1/s and incident Froude number 3.69. 
These data were compared to the data collected by Endres (1990) and Drapeau et al. (1997).

Endres (1990) collected instantaneous pressure data on the experimental model of a stilling basin downstream of a chute spillway. This channel, $0.72 \mathrm{~m}$ wide and $15 \mathrm{~m}$ long, was built in the Instituto de Pesquisas Hidráulicas (IPH) of Universidade Federal do Rio Grande do Sul in Brazil (UFRGS/BR). Pressure samples with a frequency of $100 \mathrm{~Hz}$ were collected during $100 \mathrm{~s}$ by 11 pressure transducers installed in the flat bottom of the channel (Figure 3) for five flow situations, characterized by the Froude number ranging from 4.3 to 8.6.

Drapeau et al. (1997) conducted tests on a hydraulic model equipped with a discharge system identical to the one used by Endres (1990). This was done on purpose, to study the laboratory effects and to verify if the data collected on similar models would yield similar data. The channel used by Drapeau et al. (1997), however, was smaller (0.60 $\mathrm{m}$ wide and $12 \mathrm{~m}$ long). This study was carried out in Québec, Canada in the Laboratoire d'Hydraulique du Departement Génie Civil de l'Université Laval (Laval). Pressure samples were collected at a frequency of $50 \mathrm{~Hz}$ for $200 \mathrm{~s}$ in 22 points (Figure 4), for six flow conditions with Froude numbers between 4.2 and 9.3.

A compilation of the data collected in this study and the data gathered from other researches is shown in Table 2. Mean values and standard deviations for each flow condition and for each pressure point are shown in Figure 5 (made dimensionless with the methodology presented next).

\section{METHODS}

As stated by Lopardo (2013a), for proper understanding of the internal flow and turbulence characteristics of the hydraulic jump on a stilling basin, mean flow and fluctuating motion must be assessed. According to Drapeau et al. (1997), in the statistical approach to describe the pressures caused by the hydraulic jump, the pressure distribution differs from the Gaussian distribution. Therefore, it is better described by Equation 4, in which $\mathrm{P}_{\mathrm{x}^{0}}$ represents the pressure with $\mathrm{x} \%$ probability of not being exceeded at point $\mathrm{X}, \mathrm{P}_{\mathrm{x}}$ represents the mean pressure at point $\mathrm{X}, \sigma_{X}$ represents pressure fluctuations at point $\mathrm{X}$ and $N_{x \%}$ represents the statistical coefficient of probability distribution for the relative position $\frac{X}{y_{2}-y_{1}}$ in the stilling basin.

$P_{x \%}=P_{X} \pm N_{x \%} \cdot \sigma_{X}$

The methodology described was used in combination with the dimensionless relationships (Equations 5, 6 and 7) suggested by Drapeau et al. (1997) in order to compare the data analyzed in this study with the data collected by Endres (1990) and Drapeau et al. (1997). The parameters are described in Figure 6.

$$
\begin{gathered}
\Psi=\frac{P_{x}-y_{I}}{y_{2}-y_{1}} \\
\Omega=\frac{\sigma_{x} \cdot y_{2}}{H_{t} \cdot y_{I}} \\
\Gamma=\frac{X}{y_{2}-y_{I}}
\end{gathered}
$$

where: $\Psi$ is the dimensionless mean pressure; $\Omega$ is the dimensionless pressure fluctuation; $\Gamma$ is the dimensionless longitudinal position along the stilling basin; $X=$ horizontal distance correspondent to the beginning of the hydraulic jump, starting at the joint of the toe curve of the spillway with the flat section of the stilling basin; $y_{1}=$ rapid sequent depth of the hydraulic jump; $y_{2}=$ slow

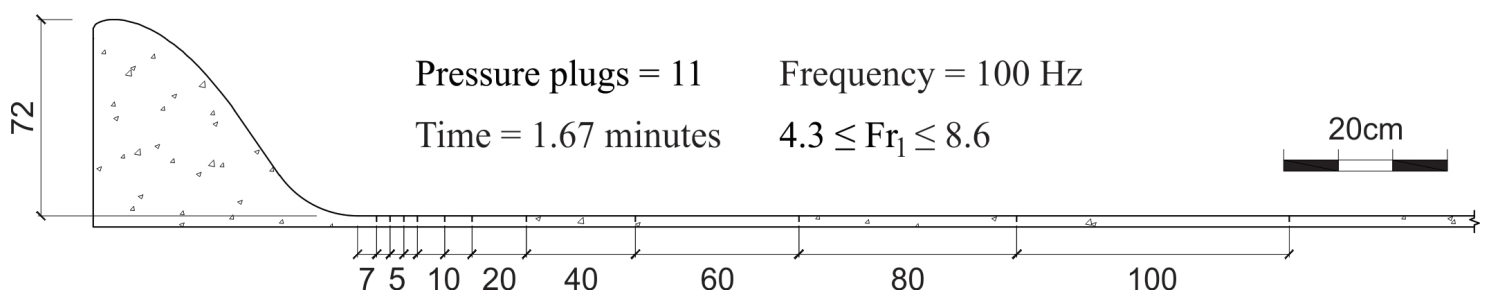

Figure 3. Experimental model (IPH/UFRGS/Brazil) and pressure transducers locations (Endres, 1990).

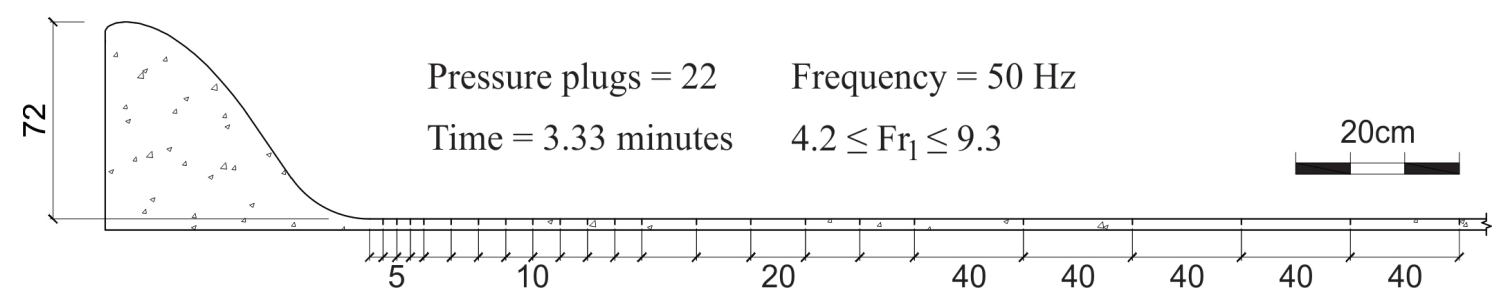

Figure 4. Experimental model (Laval/Canada) and pressure transducers locations (Drapeau et al., 1997).

Table 2. Information about the data collected in this study and data from other researches (Endres, 1990; Drapeau et al., 1997).

\begin{tabular}{lccccc}
\hline \multicolumn{1}{c}{ Research } & Pressure taps & $\begin{array}{c}\text { Flow conditions } \\
\text { tested }\end{array}$ & $\begin{array}{c}\text { Acquisition } \\
\text { frequency (Hz) }\end{array}$ & $\begin{array}{c}\text { Duration of test } \\
\text { (s) }\end{array}$ & $\begin{array}{c}\text { Total number of } \\
\text { data }\end{array}$ \\
\hline Endres (1990) & 11 & 5 & 100 & 100 & 550,000 \\
Drapeau et al. (1997) & 22 & 6 & 50 & 200 & $1,320,000$ \\
Present study & 4 & 6 & 100 & 600 & $1,440,000$ \\
\hline
\end{tabular}




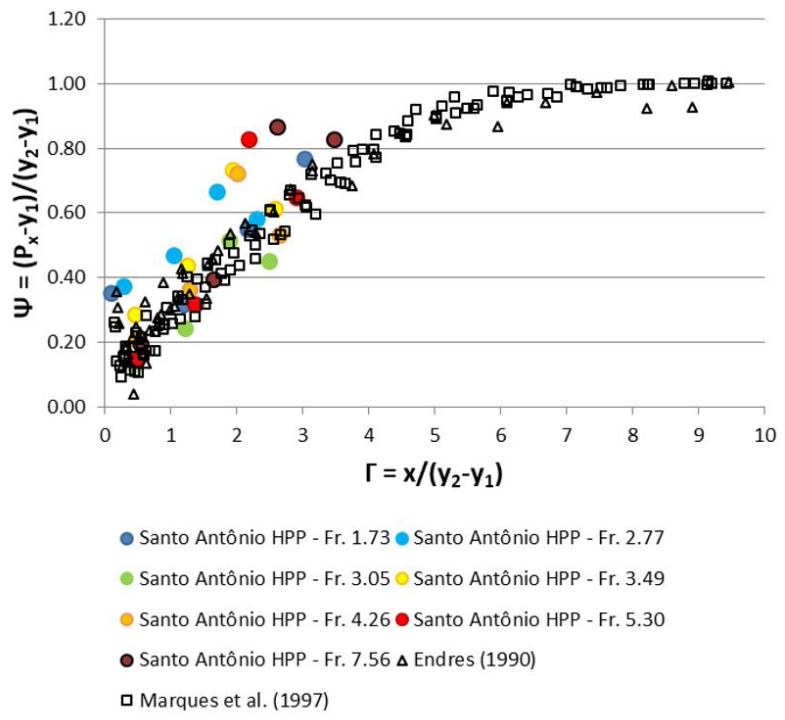

(a)

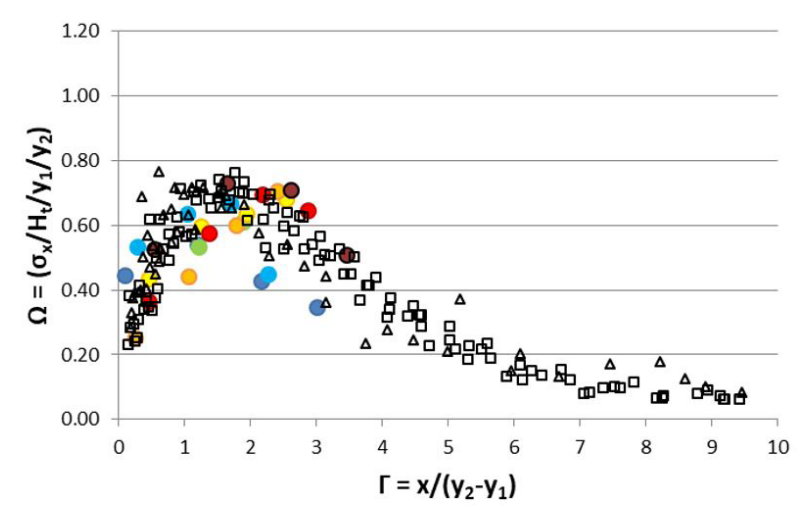

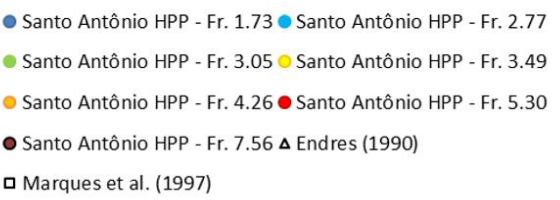

(b)

Figure 5. Comparison between sampled data collected in the two-dimensional model of the Santo Antônio HPP and data collected by Endres (1990) and Drapeau et al. (1997): (a) mean pressure samples; (b) pressure fluctuations.

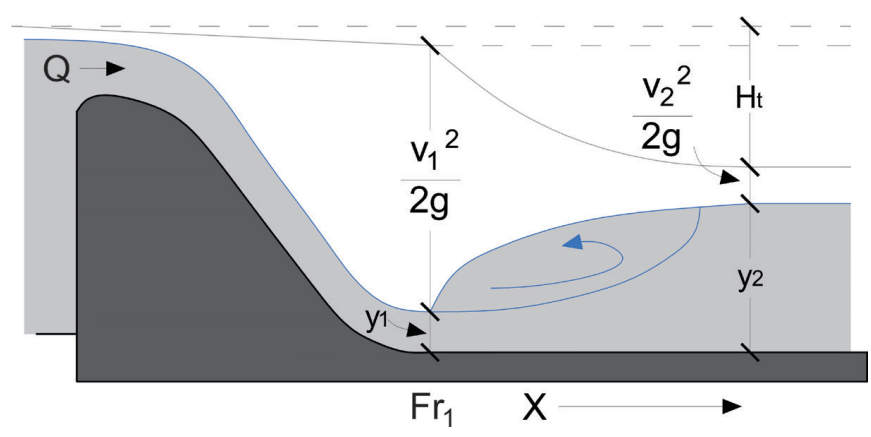

Figure 6. Description of parameters used in the methodology presented by Drapeau et al. (1997). Q is flowrate; $\mathrm{Fr}_{1}$ is the incident Froude number; $\mathrm{y}_{1}$ and $\mathrm{y}_{2}$ are the sequent depths; $\mathrm{v}_{1}$ and $\mathrm{v}_{2}$ are the velocities at each section; $\mathrm{X}$ is the horizontal distance to the start of the jump; and $\mathrm{H}_{t}$ is the total head loss along the hydraulic jump.

sequent depth of the hydraulic jump; $H_{t}=$ total head loss along the hydraulic jump.

Teixeira (2003) provided a methodology based in the quadratic approximation of each parameter of Equation 4 and the relations presented by Equations 5, 6 and 7. Dimensionless mean pressure $\Psi$, dimensionless pressure fluctuations $\Omega$ and the coefficient of probability distribution $N_{x \%}$ are based on fixed coefficients, the longitudinal position of the jump, the sequent depths and head loss (Equations 8, 9 and 10). In order to derive each one of the proposed adjustments, the author used data from model studies as well as prototype data. In addition to the data collected by Endres (1990) and Drapeau et al. (1997), Teixeira (2003) also used data collected by Pinheiro (1995) on a model equipped with 11 pressure transducers, registering pressure values with a frequency of $16 \mathrm{~Hz}$ for 5 different Froude numbers varying between 6 and 10. Mean pressure data collected on a model of Canabrava HPP, located in Furnas Centrais Hidrelétricas, Rio de
Table 3. Coefficients a, b and c for the determination of the statistical coefficient of probability distribution (Teixeira, 2003; Hampe, 2018).

\begin{tabular}{cccc}
\hline $\begin{array}{c}\text { Probability of } \\
\text { non-exceedance }\end{array}$ & $\mathbf{a}$ & $\mathbf{b}$ & $\mathbf{c}$ \\
\hline $99.9 \%$ & 0.0021 & -0.3172 & 5.0504 \\
$99 \%$ & 0.0317 & -0.3598 & 3.3008 \\
$95 \%$ & 0.0171 & -0.1393 & 1.8624 \\
$90 \%$ & 0.0048 & -0.0325 & 1.2695 \\
$80 \%$ & -0.0016 & 0.0297 & 0.6846 \\
$70 \%$ & -0.0048 & 0.0589 & 0.3313 \\
$60 \%$ & -0.0075 & 0.0750 & 0.0587 \\
$50 \%$ & -0.0076 & 0.0759 & -0.1635 \\
$40 \%$ & -0.0064 & 0.0627 & -0.3631 \\
$30 \%$ & -0.0076 & 0.0610 & -0.5808 \\
$20 \%$ & -0.0036 & 0.0260 & -0.8036 \\
$10 \%$ & -0.0032 & -0.0450 & -1.0869 \\
$5 \%$ & 0.0130 & -0.1323 & -1.3061 \\
$1 \%$ & 0.0512 & -0.4480 & -1.6601 \\
$0.1 \%$ & 0.1353 & -1.1957 & -1.9377 \\
\hline
\end{tabular}

Janeiro, Brazil, was also used in this study, as well as prototype data collected in Porto Colômbia HPP in 1996 (7 pressure points, $\left.100 \mathrm{~Hz}, 3,88 \leq \mathrm{Fr}_{1} \leq 8,08\right)$. Coefficients a, b and c, shown in Table 3, vary according to the probability of non-exceedance of pressure amplitudes. Teixeira (2003) introduced these coefficients for probabilities of non-exceedance between 1\% and 99\%. Later on, Hampe (2018) expanded this range, introducing coefficients valid also for $0.1 \%$ and $99.9 \%$.

$$
\begin{aligned}
& \Psi=-0.015 \cdot \Gamma^{2}+0.237 \cdot \Gamma+0.07 \\
& \Omega=\left\{\begin{array}{c}
-0.159 \cdot \Gamma^{2}+0.573 \cdot \Gamma+0.19,0 \leq \Gamma \leq 2.4 \\
0.017 \cdot \Gamma^{2}-0.281 \cdot \Gamma+1.229,2.4<\Gamma \leq 8.25
\end{array}\right.
\end{aligned}
$$


$N_{a \%}=a \cdot \Gamma^{2}+b \cdot \Gamma+c$

Equations 8 and 10 are valid for $0 \leq \Gamma \leq 8$.

This methodology was applied to the present data to obtain estimates of extreme values of pressure acting on a dissipation basin downstream of a low head spillway. The estimated values were compared to the actual extreme values collected on the model tests, for the probabilities of non-exceedance of $0.1 \%$, $1 \%, 99 \%$ and $99.9 \%$.

The evaluation of the proximity between extreme pressure estimations and sample was performed by calculating the relative error $E r_{x \%}$ between the sample pressures $P_{\text {sample }}$ and estimations $P_{\text {calc }}$ according to Equation 11.

$E r_{x \%}=\frac{P_{\text {sample }}-P_{\text {calc }}}{P_{\text {sample }}}$

\section{Pressure samples}

From the analysis of the pressure samples collected in the two-dimensional model of the Santo Antônio HPP and comparison with Endres (1990) and Drapeau et al. (1997), it was observed that Santo Antônio HPP's mean pressure samples were similar or higher than other data (Figure $5 \mathrm{a}$ ). Especially between dimensionless longitudinal positions 1.5 and 3.5 , pressure values were higher than the reference data, for different flow conditions. Since there was no clear behavior distinction from low Froude number flows to the others, there could be influence of the geometrical differences of the models, such as the toe curve between spillway and stilling basin, presence of gate, ratio of discharge, upstream and downstream water levels and elevation of spillway crest, etc. The pressure fluctuations (Figure 5b), however, presented a

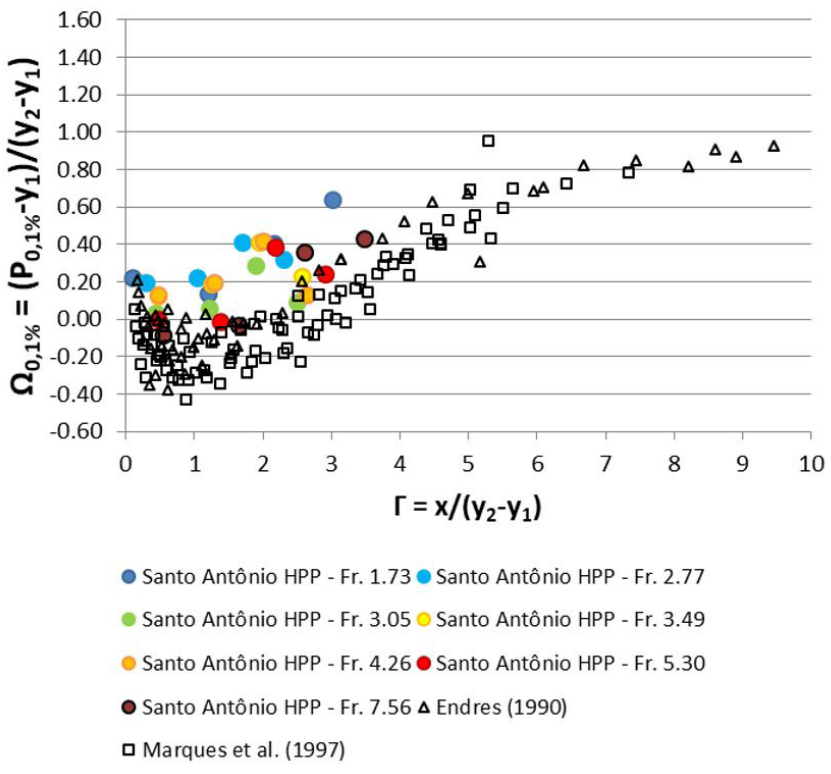

(a) similar behavior when compared to the data obtained by Endres (1990) and Drapeau et al. (1997). The exceptions were the two tests with lower Froude number (1.73 and 2.77). In the initial part of the jump, these fluctuation values were higher than the reference curve. However, for dimensionless positions between 2.0 and 3.0, pressure fluctuations stood lower than other author's data. Because the pressure transducers were installed only in the initial part of the basin, it is not possible to infer if the pressure fluctuations follow the tendency shown by the other author's data.

The extreme pressures with probability of non-exceedance of $0.1 \%$ and $1 \%$ are shown in Figure 7 . Santo Antônio HPP sample presented similar or higher pressure values when compared to Endres (1990) and Drapeau et al. (1997). Similar to the mean pressure results, there was no clear indication that the different tendencies are due solely to the different Froude number of the hydraulic jumps. The extreme pressures with probability of non-exceedance of $99 \%$ and $99.9 \%$ (Figure 8) presented similar or inferior values when compared to Endres (1990) and Drapeau et al. (1997). Results from Figure 7 and Figure 8 might be indicating a softening effect caused by the water cushion formed in hydraulic jumps downstream of low head spillways. This cushion can be seen in Figure 2, under the two-phase zone, where air is entraining the jump.

\section{Pressure forecasting}

The pressure forecasting method proposed by Teixeira (2003) was applied to Santo Antônio HPP parameters in order to provide an estimation of the mean and fluctuating pressures and the extreme pressure efforts with $0.1 \%, 1 \%, 99 \%$ and $99.9 \%$ probability of non-exceedance for the flows with Froude numbers ranging from 1.73 to 7.56 . The results were compared with the correspondent pressure samples and the precision of the method

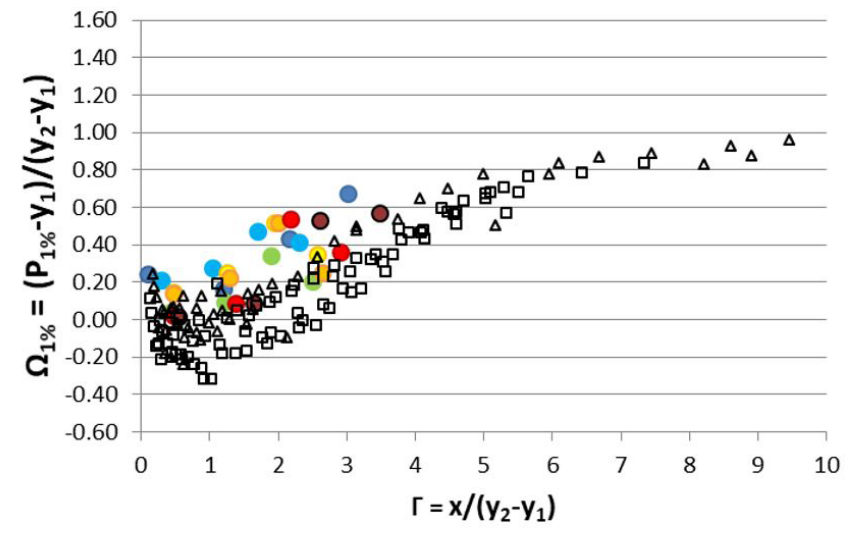

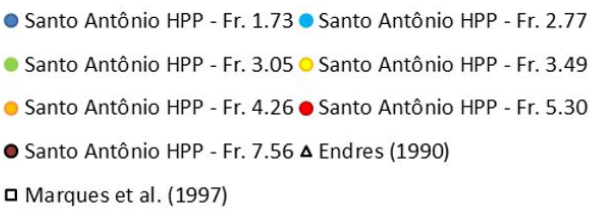

(b)

Figure 7. Comparison between sampled data collected in the two-dimensional model of the Santo Antônio HPP and data collected by Endres (1990) and Drapeau et al. (1997): (a) $\mathrm{P}_{0.1 \%}$ pressure samples; (b) $\mathrm{P}_{1 \%}$ pressure samples. 
was evaluated according to the relative error between estimation and sampled value.

From Figure 9a, it is possible to conclude that the methodology proposed by Teixeira (2003) is adequate for the estimation of mean pressures through all the analyzed range of Froude numbers, especially for those above 3.05. The third pressure transducer, however, presented a few discrepancies. Figure $9 \mathrm{~b}$ shows that the relative error obtained from the pressure fluctuations were up to approximately \pm 0.2 .

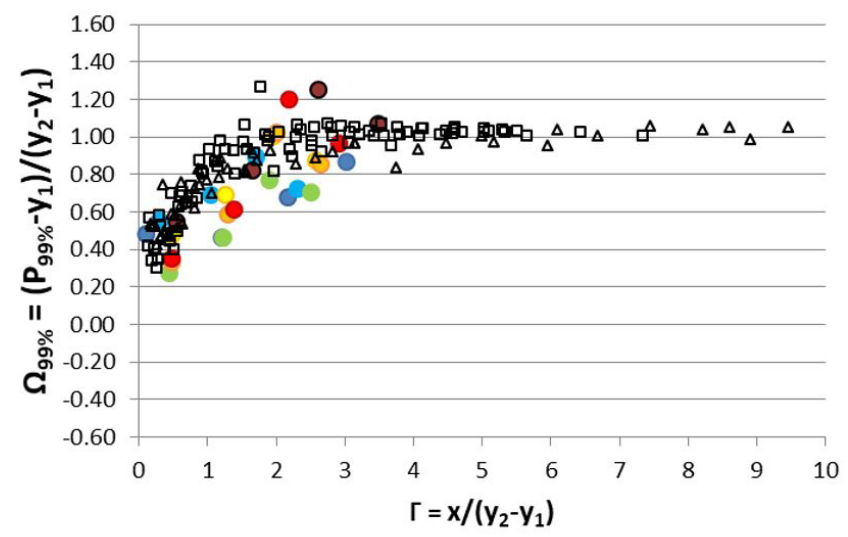

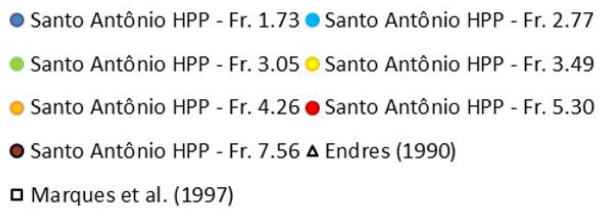

(a)
The pressure fluctuations estimated through the methodology proposed by Teixeira (2003), as presented in Figure 10a, did not yield sufficiently good results. The results were worse for lower Froude numbers. In addition, a peculiar pattern was observed for the sample pressure fluctuation of Froude number 1.73. This might be because it is around the limit suggested by the literature between the undular jump and the pre-jump. In Figure 10b, it is seen that the relative error obtained from the pressure fluctuations estimations were higher than the mean pressure

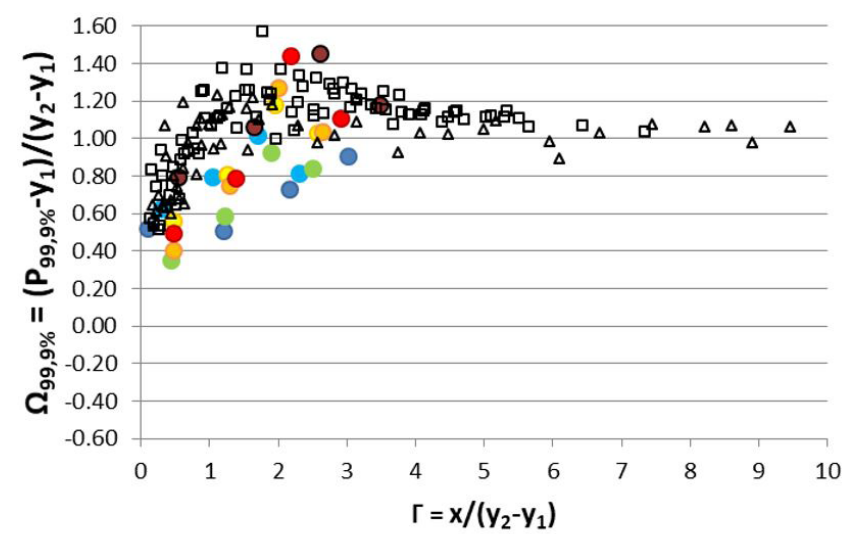

- Santo Antônio HPP - Fr. 1.73 • Santo Antônio HPP - Fr. 2.77
- Santo Antônio HPP - Fr. 3.05 Santo Antônio HPP - Fr. 3.49
- Santo Antônio HPP - Fr. 4.26 Santo Antônio HPP - Fr. 5.30
- Santo Antônio HPP - Fr. $7.56 \Delta$ Endres (1990)
ם Marques et al. (1997)

(b)

Figure 8. Comparison between sampled data collected in the two-dimensional model of the Santo Antônio HPP and data collected by Endres (1990) and Drapeau et al. (1997): (a) $\mathrm{P}_{99 \%}$ pressure samples; (b) $\mathrm{P}_{99.9 \%}$ pressure samples.

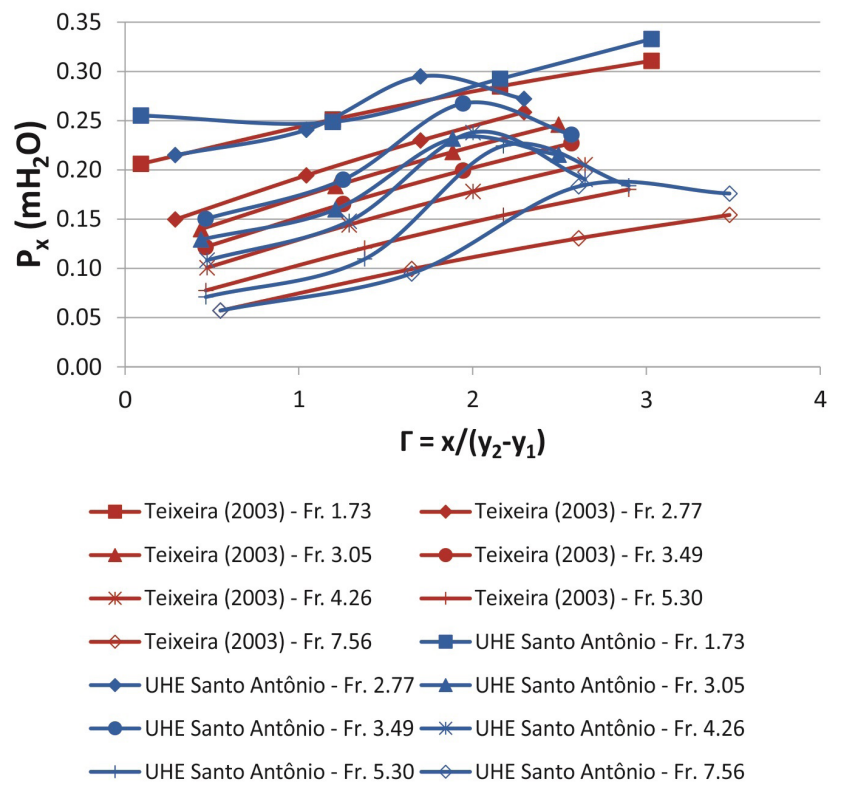

(a)

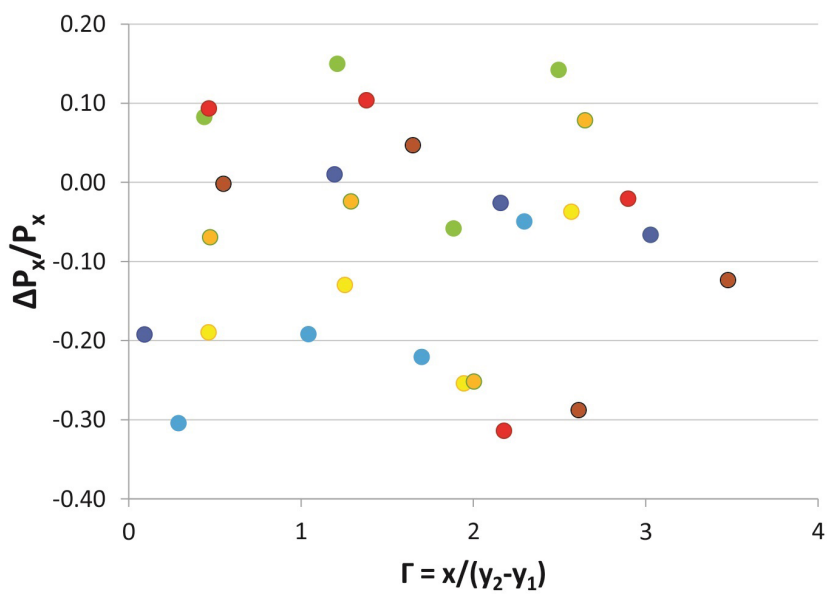

- Santo Antônio HPP - Fr. 1.73 - Santo Antônio HPP - Fr. 2.77 - Santo Antônio HPP - Fr. 3.05 Santo Antônio HPP - Fr. 3.49 O Santo Antônio HPP - Fr. 4.26 Santo Antônio HPP - Fr. 5.30 - Santo Antônio HPP - Fr. 7.56

(b)

Figure 9. Application of the methodology proposed by Teixeira (2003) and sample data: (a) mean pressure; (b) relative error. 
results. It is noticeable that deviations associated with higher Froude numbers presented lower relative errors. Furthermore, the estimation of the pressure fluctuations associated with the $\mathrm{Fr}_{1}$ 1.73 flow did not meet expectations. These results suggest some influence of the Froude number in the pressure fluctuations,

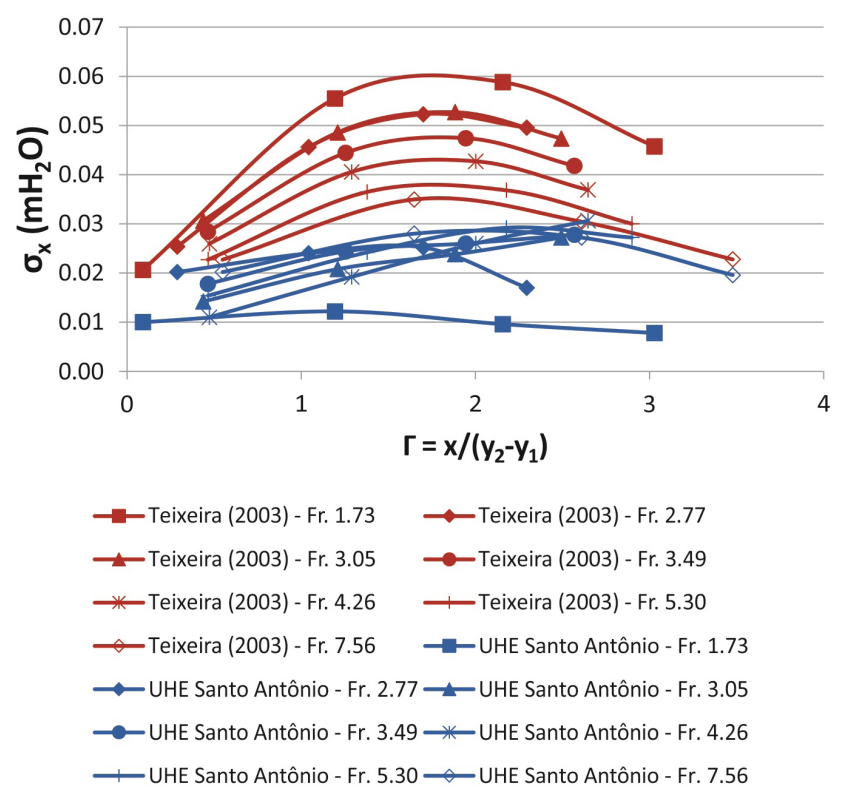

(a) even though it is not the only reason for the differences verified between Santo Antônio HPP pressure fluctuations results and other samples as well as for its forecasting.

In Figure 11, the relative error of the extreme pressure estimations is presented for the probabilities of non-exceedance

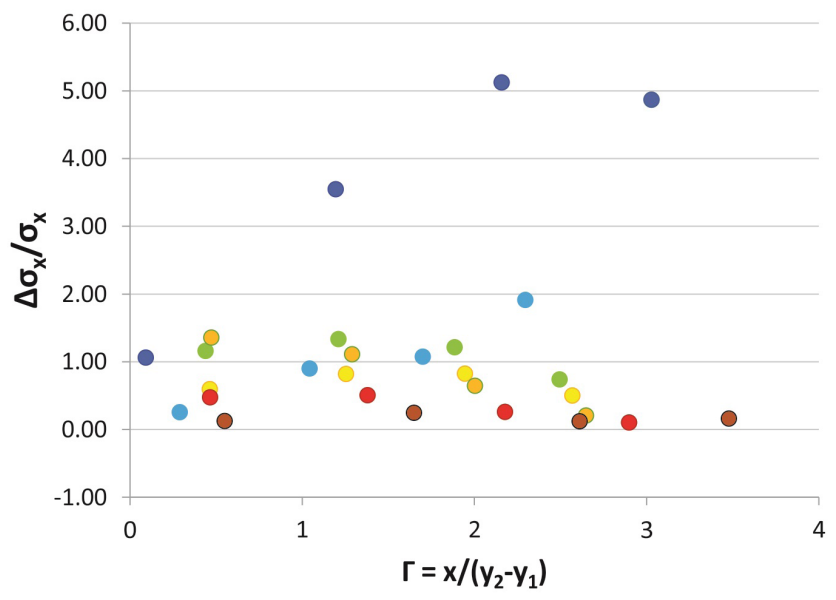

- Santo Antônio HPP - Fr. 1.73 • Santo Antônio HPP - Fr. 2.77

- Santo Antônio HPP - Fr. 3.05 Santo Antônio HPP - Fr. 3.49

- Santo Antônio HPP - Fr. 4.26 ๑ Santo Antônio HPP - Fr. 5.30

- Santo Antônio HPP - Fr. 7.56

(b)

Figure 10. Application of the methodology proposed by Teixeira (2003) and sample data: (a) pressure fluctuation; (b) relative error.

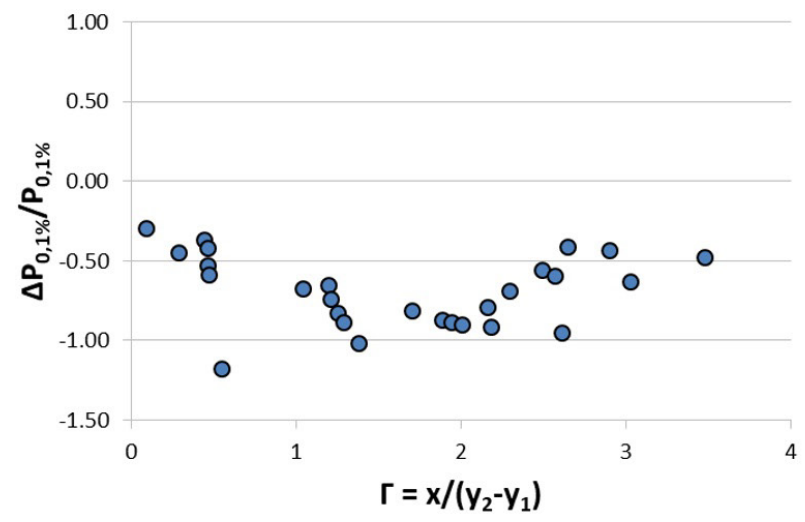

(a)

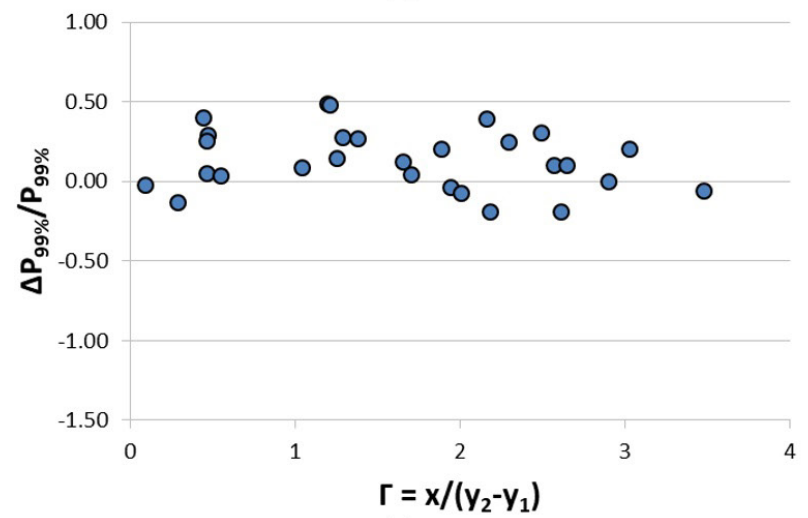

(c)

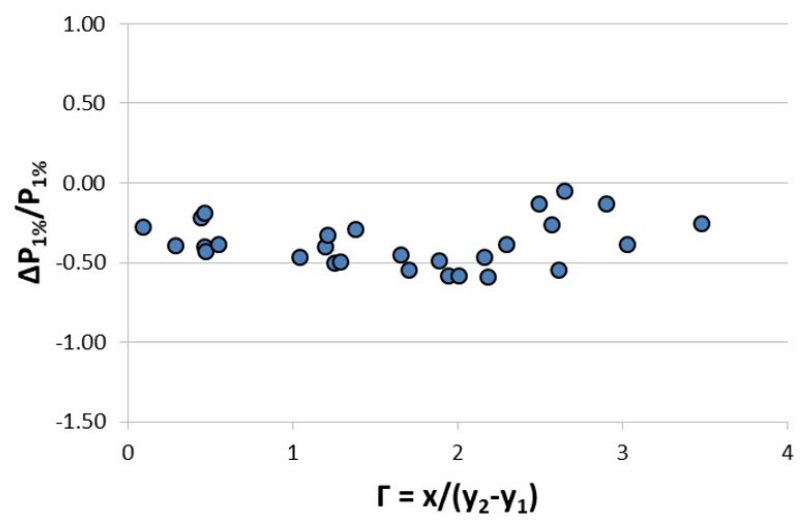

(b)

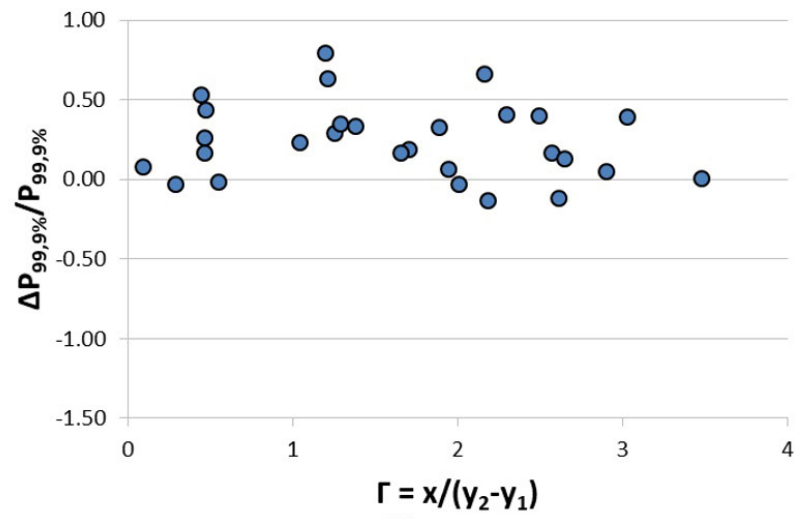

(d)

Figure 11. Relative error from the application of the methodology proposed by Teixeira (2003): (a) $\mathrm{P}_{0.1 \%}$; (b) $\mathrm{P}_{1 \%}$; (c) $\mathrm{P}_{99 \%}$; (d) $\mathrm{P}_{99.9 \%}$. 
$0.1 \%, 1 \%, 99 \%$ and $99.9 \%$. One outlier was excluded from the evaluation related to the probability of non-exceedance $0.1 \%$. For the remaining results, the forecasting of $\mathrm{P}_{0.1 \%}$ and $\mathrm{P}_{99.9 \%}$ resulted in relative errors up to approximately \pm 1.0 , which corresponds to an absolute error of $11.5 \mathrm{mH} 2 \mathrm{O}$ in prototype value. The relative error related to the prediction of $\mathrm{P}_{1 \%}$ and $\mathrm{P}_{99 \%}$ resulted in values of approximately \pm 0.6 . Thus, the results indicate that the pressure forecasting methodology proposed by Teixeira (2003) can be applied for situations similar to the Santo Antonio HPP, for the whole range of Froude numbers of the sample, assuming the error verified. Even though the estimation of the pressure fluctuations was not accurate, it did not affect the extreme pressure determination considerably.

\section{CONCLUSION}

This study aimed to assess the applicability of the pressure forecasting methodology proposed, based on a statistical distribution of pressure by Teixeira (2003), for the prediction of extreme pressures in the hydraulic jump with low Froude number (below 4.5). The assessment of pressure samples indicated that mean pressure differences were not strongly related to the Froude number but possibly to geometrical differences (i.e. radius of toe curve between spillway and stilling basin, relationship between water levels, discharge, elevation of spillway crest, etc.). However, the pressure fluctuations showed a dependency on the Froude number. The efforts associated with the probabilities of non-exceedance presented less extreme values than data provided by Endres (1990) and Drapeau et al. (1997), as seen in Figure 7 and Figure 8.

The application of the methodology to the sample data collected at the two-dimensional model of Santo Antônio HPP discharge system showed that the mean pressure estimative was reasonably accurate but the pressure fluctuations was not as precise as intended (Figure 10). The extreme pressure efforts prediction was not strongly affected by the pressure fluctuations forecasting and was able to provide results with errors up to approximately \pm 1.0 . The results show that the methodology may be applied to the assessed situation in a preliminary level (Figure 11). Additional studies should be done to improve the method in order to provide results that are more accurate.

\section{REFERENCES}

Bayon, A., Valero, D., García-Bartual, R., Vallés-Morán, F. J., \& López-Jiménez, P. A. (2016). Performance assessment of OpenFOAM and FLOW-3D in the numerical modeling of a low Reynolds number hydraulic jump. Environmental Modelling \& Software, 80, 322-335. http://dx.doi.org/10.1016/j.envsoft.2016.02.018.

Bélanger, J.-B. (1828). Essai sur la solution numérique de quelques problèmes relatifs au mouvement permanente des eaux courantes. Paris: Carilian-Goeury.

Castro-Orgaz, O., Hager, W. H., \& Dey, S. (2015a). Depth-averaged model for undular hydraulic jump. Journal of Hydraulic Research, 53(3), 351-363. http://dx.doi.org/10.1080/00221686.2014.967820.
Castro-Orgaz, O., Roldán, J., \& Dolz, J. (2015b). Resalto hidráulico ondulatorio. Ingeniería del Agua, 19(2), 63-74. http://dx.doi. org/10.4995/ia.2015.3321.

Chiew, Y. M., \& Emadzadeh, A. (2017). Experimental investigation of free surface dynamics and pressure fluctuations in a closedconduit hydraulic jump. In E-Proceedings of the 37th LAHR World Congress. Kuala Lumpur, Malaysia: IAHR.

Dai Prá, M. (2011). Uma abordagem para determinação das pressões junto ao fundo de dissipadores de energia por ressalto hidráulico (Tese de doutorado). Instituto de Pesquisas Hidráulicas, Universidade Federal do Rio Grande do Sul, Porto Alegre.

Drapeau, J., Verrette, J.-L., \& Marques, M. (1997). Flutuação de pressão em um ressalto hidráulico. Revista Brasileira de Recursos Hidricos, 2(2), 45-52. http://dx.doi.org/10.21168/rbrh.v2n2.p45-52.

Elevatorski, E. A. (1959). Hydraulic energy dissipators. New York: McGraw-Hill.

Endres, L. A. M. (1990). Contribuição ao desenvolvimento de um sistema para aquisição e tratamento de dados de pressões instantâneas em laboratório (Dissertação de mestrado). Instituto de Pesquisas Hidráulicas, Universidade Federal do Rio Grande do Sul, Porto Alegre.

Hampe, R. F. (2018). Previsão de pressões extremas em bacias de dissipação por ressalto bidráulico com baixo número de Froude (Dissertação de mestrado). Instituto de Pesquisas Hidráulicas, Universidade Federal do Rio Grande do Sul, Porto Alegre.

Jesudhas, V., Balachandar, R., Roussinova, V., \& Barron, R. (2018). Turbulence characteristics of classical hydraulic jump using DES. Journal of Hydraulic Engineering, 144(6), 1-15. http://dx.doi. org/10.1061/(ASCE)HY.1943-7900.0001427.

Lopardo, R. A. (2013a). Extreme velocity fluctuations below free hydraulic jumps. Journal of Engineering, 2013, 678064. http://dx.doi. org/10.1155/2013/678064.

Lopardo, R. A. (2013b). Presiones mínimas y velocidades máximas instantáneas em um disipador a resalto hidráulico oscilante. In Proceedings of the 24th Congreso Nacional del Agua. San Juan, Argentina: Instituto Nacional del Agua.

McPherson, B. L., Lesleighter, E. J., Scriven, D. C., \& Bollaert, E. F. R. (2015). Physical and computational scour modelling system analysis-case study for Paradise Dam, Queensland. In Proceedings of the 2015 Australian National Committee on Large Dams Conference: Contemporary Challenges for Dams (pp. 1-8). Hobart, Tasmania: ANCOLD.

Peterka, A. J. (1974). Hydraulic design of stilling basins and energy dissipators. Washington: USBR.

Pinheiro, A. A. N. (1995). Acções hidrodinâmicas em soleiras de bacia de dissipaşão de energia por ressalto bidráulico (Tese de doutorado). Universidade Técnica de Lisboa, Lisboa. 
Rajaratnam, N. (1967). Hydraulic jumps. In V. T. Chow (Ed.), Advances in bydroscience. New York: Elsevier.

Souza, P. E. A. (2012). Bacias de dissipação por ressalto bidráulico com baixo número de Froude: análise das pressões junto ao fundo da estrutura (Dissertação de mestrado). Instituto de Pesquisas Hidráulicas, Universidade Federal do Rio Grande do Sul, Porto Alegre.

Teixeira, E. D. (2003). Previsão dos valores de pressão junto ao fundo em bacias de dissipação por ressalto hidráulico (Dissertação de mestrado). Instituto de Pesquisas Hidráulicas, Universidade Federal do Rio Grande do Sul, Porto Alegre.

Trierweiler, E. F. N. (2006). Avaliação do campo de pressões em ressalto bidráulico formado a jusante de uma comporta com diferentes graus de submergência (Dissertação de mestrado). Instituto de Pesquisas Hidráulicas, Universidade Federal do Rio Grande do Sul, Porto Alegre.

Valero, D., Bung, D. B., \& Crookston, B. M. (2018). Energy dissipation of a Type III Basin under design and adverse conditions for stepped and smooth spillways. Journal of Hydraulic Engineering, 144(7), 1-11. http://dx.doi.org/10.1061/(ASCE)HY.1943-7900.0001482.

Wang, H., \& Chanson, H. (2015). Experimental study of turbulent fluctuations in hydraulic jumps. Journal of Hydraulic Engineering,
141(7), 04015010. http://dx.doi.org/10.1061/(ASCE)HY.19437900.0001010 .

Witt, A., Gulliver, J. S., \& Shen, L. (2018). Numerical investigation of vorticity and bubble clustering in an air entraining hydraulic jump. Computers \& Fluids, 172, 162-180. http://dx.doi.org/10.1016/j. compfluid.2018.06.019.

\section{Authors contributions}

Roberta Ferrão Hampe: Performed the methodology, obtained the results and wrote the text.

Renato Steinke Júnior: Formatted and revised the text and the results.

Maurício Dai Prá: Contributed with technical notes and revised the text.

Marcelo Giulian Marques: Contributed with technical notes and revised the text.

Eder Daniel Teixeira: Defined the objectives and revised the text and the results. 